\title{
Standard Of Measurement For Student Evaluation Instruments
}

Kathleen Simione, Quinnipiac University, USA

David Cadden, Quinnipiac University, USA

Angela Mattie, Quinnipiac University, USA

\begin{abstract}
For colleges and universities, the expectation for excellence in teaching and learning has made development of a system for measuring teaching effectiveness critical. Teaching effectiveness is generally assessed with a comprehensive review of skills including instructional design, instructional delivery and course management. This requires student feedback usually in the form of Student Evaluation Instruments (SEIs). Since SEIs are an important part of measuring teaching effectiveness to assess excellence, and excellence in the classroom is expected when considering promotion and tenure, it follows that they play an integral role in the promotion and tenure process. In fact, faculty promotions and the issuance of tenure may hinge on the results of these vital evaluations. Our study investigates the use of SEIs at our university's School of Business. Unlike many other prior studies, limited to a single course or department and a single semester, we examined data collected from the use during six semesters (three years) of our Student Evaluation Instrument for the entire School of Business. The results yielded nearly 30,000 useable responses across all business majors. If SEIs are to be used effectively and fairly then one must have a clear understanding as to what should be the appropriate standard used to evaluate faculty teaching effectiveness. Should a global value - the mean for the entire school or university - be used or should it be based on the mean for each department? We believe this to be a critical consideration given the potential for differences in mean ratings amongst departments.
\end{abstract}

Keywords: Student evaluations, teaching ratings, performance

\section{INTRODUCTION}

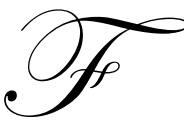

or colleges and universities, the expectation for excellence in teaching and learning has made development of a system for measuring teaching effectiveness critical. Teaching effectiveness is generally assessed with a comprehensive review of skills including instructional design, instructional

delivery and course management. This requires student feedback usually in the form of Student Evaluation Instruments (SEIs). Since SEIs are an important part of measuring teaching effectiveness to assess excellence, and excellence in the classroom is expected when considering promotion and tenure, it follows that they play an integral role in the promotion and tenure process. In fact, faculty promotions and the issuance of tenure may hinge on the results of these vital evaluations.

\section{LITERATURE REVIEW}

\section{Importance}

While other measures of teaching effectiveness may be employed by universities and colleges such as student performance, classroom observations, faculty self-reports, SEIs receive more scrutiny from administrators and faculty than do other measures of teaching effectiveness (Seldin,1993). As noted, decisions about faculty tenure, promotion, and merit pay raises often rely heavily on information obtained from SEIs (Kulik, 2001). In the 
Comm et al. survey, $63.4 \%$ of the responding Deans indicated student evaluations were very important to important in tenure and promotion decisions (Comm et al., 1998).

The importance of SEIs themselves can be seen in the vast available literature. Al-Issa and Sulieman (2007) found 2988 articles on SEIs published between 1990 and 2005. Therefore, it is not surprising that this method of evaluating teaching performance has gained wide spread use in most universities and colleges (Hobson \& Talbot, 2001; Richardson, 2005) and is often the primary method used to evaluate classroom teaching performance (Yunker \& Sterner, 1988). Comm and Mathaisel (1998) indicate that almost all AACSB accredited business schools responding to a survey use Student Evaluation Instruments as an element in determining teaching effectiveness.

\section{Validity}

Much of the SEI literature examines the validity of the SEI as a tool to assess teaching effectiveness (Clayson and Sheffet 2006; Glynn et al. 2006; Green et al. 1998; Soper 1973; Rodin and Rodin 1973; Sopher 1973; Morgan et al. 2003). While the literature does provide examples to support the validity of SEIs (Aleamoni, 1999; Wachtel, 1998), serious questions exist as to whether SEIs should be used as a primary measure of teaching effectiveness. Particularly when the instrument is used to determine tenure, promotion or pay raises.

Controversy over the legitimacy of SEIs extends to the relative importance of exogenous factors such as personality, course workload and organization, type of course (requirement for the business core, requirement for the major, or an elective), grading leniency (inflation), and other instructor variables. Clayson and Sheffet (2006) found a strong relationship between students' perception of the instructor's personality and their evaluation of instructional effectiveness in marketing and business core courses. They raised a concern that if certain personality traits positively or negatively influence evaluations then learning may not be adequately assessed through the SEI. Aigner and Thum (1986) found that instructor's enthusiasm, along with other factors, exhibited significant positive influences on an instructor's rating.

\section{Course Workload And Organization}

The impact of course workload on SEIs can also be found in the existing literature. Results demonstrate that increased course demands as measured by materials, workload, and homework resulted in lower evaluations (Paswan and Young, 2002; Stapelton et al. 2001). Aigner and Thum (1986) findings also supported that course demands in terms of hours per week required outside of class had a significant negative impact. However, a more recent study focusing only on engineering courses illustrated no correlation between workload and overall instructor performance (Dee, 2007). Course organization was also seen as a factor in SEI ratings. According to Boex (2000), students perceive the most dominant attribute of an effective economics instructor to be organizational skills and clarity.

\section{Course Type}

With regard to course type, the available research has shown a relationship between the student's reason for taking the course (requirement for the school core, requirement for the major, or an elective) and the student's perception of the professor. Elective courses are rated higher than non-elective courses (Marsh, 1987; Feldman, 1978). Required courses outside the student's major receive the lowest ratings (Marsh, 1987; Feldman, 1978). Additionally, business students consistently provide lower rankings to their professors than those students majoring in the humanities (Feldman, 1978; Marsh, 1987). Moreover, Boex (2000) notes that student-instructor interaction had a significant positive impact on effectiveness ratings in core-level courses but not for non-core level courses. As he suggests, this should be considered when staffing core-level courses.

\section{Grade Inflation}

One of the major controversies surrounding SEIs is the impact of this evaluation method on grade inflation. This is understandable given the consistent findings noted that higher expected grades are associated with better 
evaluations of teaching (Nelson and Lynch 1984; Mehdizadeh 1990; Stratton et al. 1994; Isley and Singh 2005; McPherson 2006). Even more disconcerting is Yunker's (2003) findings that students who had been in an introductory accounting class that was rated more highly tended to do worse in the subsequent accounting course than students who had the teacher that was rated less highly. These studies suggest that the quest for positive teaching evaluations may lead to grade inflation. Further fueling the debate whether teaching evaluations should be the primary method of evaluating teaching effectiveness or at the very least these instruments should be interpreted with care and attention given to the impact of those variables unrelated to instructional factors.

\section{Instructor Variables}

Along with course characteristics, the existing literature examines instructor variables for their influence on student rankings of professors. Researchers have recently focused on the possibility of race bias on student evaluations of teaching effectiveness. Smith and Anderson (2005) identified the lowest course evaluation ratings for female Hispanic faculty when compared to their Anglo counterparts. A recent study by Smith (2007) found that Black faculty received lowest mean scores while white faculty received the highest. In 2005, Campbell et al. (2005) researched instructor appearance and disputed previous colleague's findings that more attractive instructors receive significantly better student evaluations than their less attractive counterparts. (Hammermesh and Parker, 2003) Campbell et al. found by controlling for certain independent variables attractiveness of the instructor did not impact students' evaluation of teaching (Campbell, 2005).

\section{Methodology Criticisms}

Besides controversy over the legitimacy of SEIs relative to the importance of a variety of exogenous factors, the significant literature on SEI bias has been also criticized for being methodologically flawed. Among several methodological problems identified by Marsh (1987) in this type of research were implying causation from correlation, use of an inappropriate unit of analysis, and not properly accounting for the multivariate nature of SEIs and potential biases. Ceci and Williams noted: "student ratings can make or break the careers of instructors on grounds unrelated to objective measures of student learning" (Ceci \& Williams, cited in Wilson, 1998).

All of these varied factors, support the issue that SEIs should not be the sole basis for evaluation. Green et al. (1998) recommend that accounting departments should reevaluate their SEIs to remove items that students cannot assess. Further, they note that SEIs should be designed to capture data on course materials and curriculum design/course development and other relevant dimensions of effective teaching. In defense of SEIs, Kanagaretnam et al. (2003), showed that the use of student evaluations in the assessment of professors "had a positive impact as they had the potential to improve the professor effort and consequently the acquired knowledge of students."

\section{Measurement Standard}

Although the literature regarding factors impacting SEIs is extensive, it often does not consider the standard by which to measure performance. Further, most studies focus on a single department. If a study does focus on multiple departments there does not appear to be a distinction made amongst departments. Consequently, the major purpose of this research was to investigate what value should be used to evaluate faculty members. Should a global value - the mean for the entire school - be used or should it be based on the mean for each department? Given the potential for differences amongst department mean scores, we believe our research can provide insight as to the most appropriate standard of measure and help to advance the SEI literature.

\section{METHOD}

\section{Sample}

Regardless of one's stance with respect to SEIs, extensive support exists for its continued use. Therefore, examination of how to best use the data from these instruments will continue to be an important part of measuring teaching effectiveness. As such, our preliminary study investigates the use of SEIs at our university's School of 
Business. As noted, unlike many other prior studies, limited to a single course or department and a single semester, we examined data collected from our Student Evaluation Instrument for six semesters (three years) for the entire School of Business. The results yielded nearly 30,000 useable responses across all business majors.

Our examination centered on two questions from our University's School of Business SEI, the students' evaluation of the instructor's Teaching Ability and whether the student would Recommend this instructor to a friend. At our institution, when evaluating a faculty member for continued employment, promotion and tenure these two items take precedence in terms of importance.

\section{Student Evaluation Instrument}

The current SEI has been in use in our School of Business for more than ten years. It was initially adopted as part of an overall assessment program which was an important element in the school's successful drive for AACSB accreditation. It is composed of twenty-one closed end questions and two open-ended questions - see Appendix 1. The closed end questions include four general questions: 1) the students' status (freshman, sophomore, junior, senior or graduate student); 2) whether the class is in the business core, the major's core or an elective; 3 ) the extent to which the student is keeping up with materials for the course; and 4) the expected grade. To maintain anonymity, the instrument intentionally collects little in the way of demographic data beyond the students' status. The other seventeen closed end questions are on a five-point Likert scale. They address the instructors' competency and the students' satisfaction with aspects of the course.

As mentioned, our study centered on two items, students' evaluation of the instructor's Teaching Ability and whether the student would Recommend this instructor to a friend. The coding is such that the more favorable the evaluation of the instructor's teaching ability the higher the score (1-Poor 5-Excellent); while the greater the likelihood that a student would recommend the instructor to a friend the lower the score (1-Strongly Agree to Recommend 5-Strongly Disagree to Recommend). Because of the importance of these two items in the overall evaluation of a faculty member, these two Likert-scaled questions were analyzed.

\section{RESULTS}

\section{Total Sample}

Table 1 provides the number of observations, mean score, and standard deviation for the total sample by semester for the two Likert-scale questions of highest importance in our promotion and tenure process, Teaching Ability and Recommendation.

Table 1: Teaching Ability and Recommendation Scores by Semester

\begin{tabular}{|l|c|c|c|c|c|c|}
\hline & \multicolumn{3}{|c|}{ Teaching Ability } & \multicolumn{3}{c|}{ Recommend Teacher } \\
\hline & $\underline{\text { Count }}$ & $\underline{\text { Mean }}$ & $\underline{\text { Std. Dev. }}$ & $\underline{\text { Count }}$ & $\underline{\text { Mean }}$ & $\underline{\text { Std. Dev. }}$ \\
\hline Fall 2002 & 4,312 & 3.91 & 1.07 & 4,199 & 1.88 & 1.14 \\
\hline Spring 2003 & 4,605 & 3.84 & 1.10 & 4,499 & 1.94 & 1.16 \\
\hline Fall 2003 & 5,348 & 3.88 & 1.08 & 5,224 & 1.93 & 1.16 \\
\hline Spring 2004 & 5,395 & 3.91 & 1.04 & 5,287 & 1.90 & 1.11 \\
\hline Fall 2004 & 5,212 & 3.78 & 1.16 & 4,848 & 1.95 & 1.15 \\
\hline Spring 2005 & 4,724 & 3.96 & 1.05 & 4,612 & 1.88 & 1.13 \\
\hline Overall & 29,596 & 3.88 & 1.09 & 28,660 & 1.91 & 1.14 \\
\hline
\end{tabular}

To clearly illustrate any differences by semester across the entire School of Business, figures 1 and 2 provide plots of the mean scores for both items by each of the six semesters. 


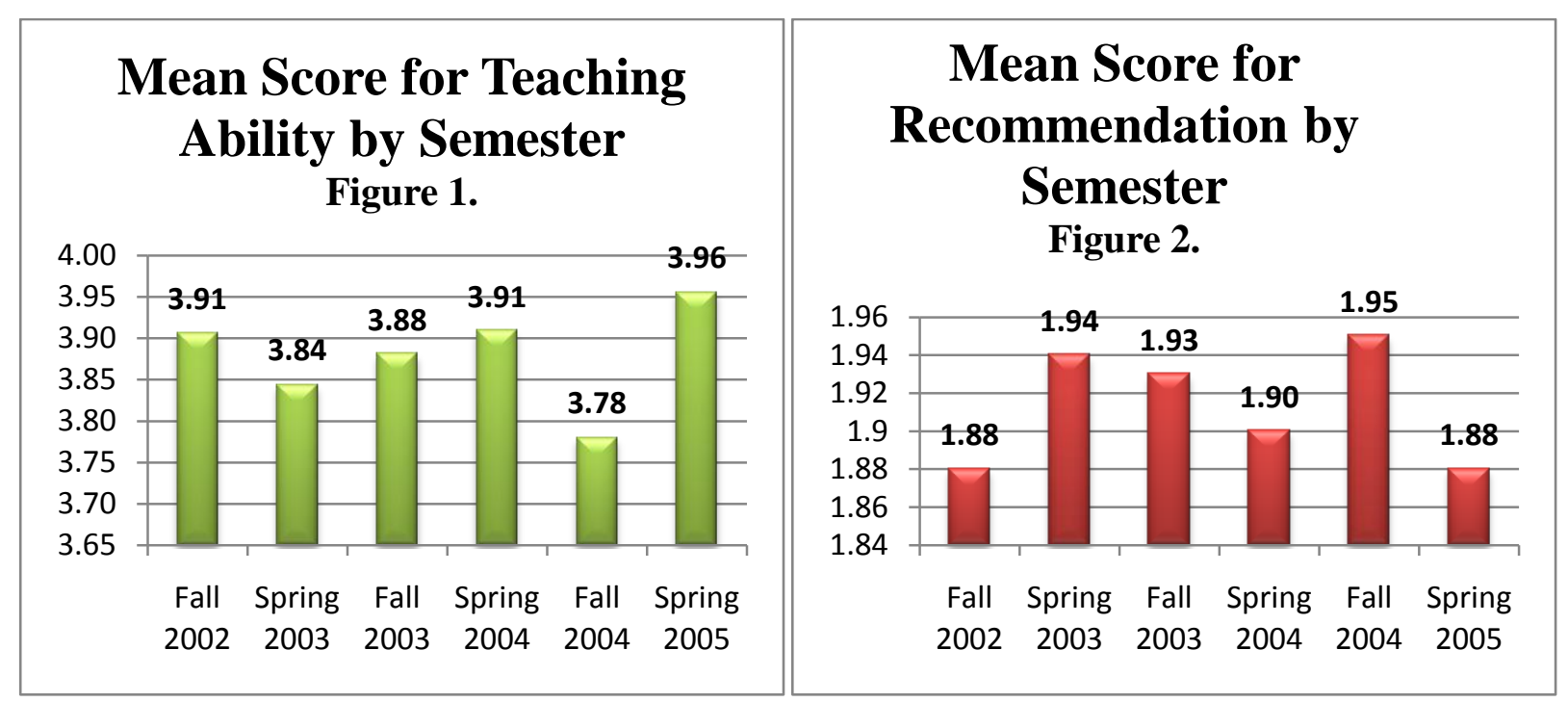

Using the overall school mean score, no significant differences resulted on both the Teaching Ability and Recommendation scores across the six semesters.

It should be noted that our evaluation instrument codes the courses by department; however, there are three sets of courses - Health Management, Business Law and Quantitative Methods - that are coded separately. We did not include these courses in our study since the instructors were not evaluated within the normal context of a departmental review. These three represent approximately $4 \%$ of the total sample. Figure 3 provides percent of total observations for the six semesters analyzed.

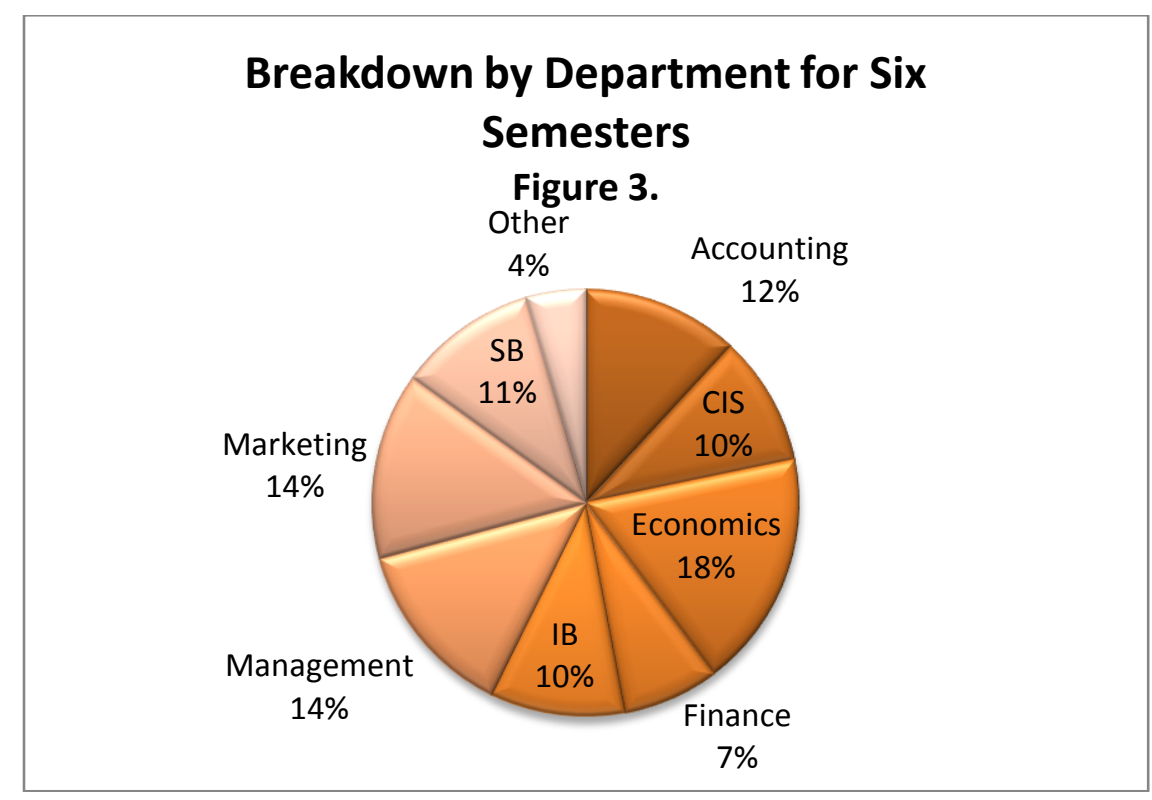




\section{Comparison Measure}

In Tables 2 and 3, we provide the mean score for Teaching Ability and Recommendation, respectively, for each semester by department. The last row in each table, School of Business, represents a number of courses given this designation. It includes our cornerstone and capstone courses along with several one credit courses. Faculty members from different departments teach in these courses. Scores from these courses are included in their evaluations; therefore, we have included them in our analysis. Data was not collected for these courses during the Fall 2002 semester.

Table 2: Mean Scores for Teaching Ability by Semester and by Department

\begin{tabular}{|l|c|c|c|c|c|c|}
\hline & F2002 & S2003 & F2003 & S2004 & F2004 & S2005 \\
\hline Accounting & 4.00 & 3.94 & 3.74 & 3.89 & 3.90 & 4.11 \\
\hline CIS & 4.11 & 3.87 & 4.11 & 4.18 & 4.14 & 4.14 \\
\hline Economics & 4.04 & 3.93 & 4.09 & 4.10 & 4.02 & 3.92 \\
\hline Finance & 3.43 & 3.66 & 3.67 & 3.97 & 3.60 & 3.86 \\
\hline IB & 3.69 & 3.79 & 3.95 & 3.73 & 3.84 & 3.50 \\
\hline Management & 3.83 & 3.66 & 3.63 & 3.96 & 3.86 & 4.02 \\
\hline Marketing & 3.99 & 3.88 & 4.22 & 4.14 & 4.06 & 4.13 \\
\hline School of Business & & 3.58 & 3.55 & 3.39 & 2.82 & 3.86 \\
\hline
\end{tabular}

Table 3: Mean Scores for Recommendation by Semester and by Department

\begin{tabular}{|l|c|c|c|c|c|c|}
\hline & F2002 & S2003 & F2003 & S2004 & F2004 & S2005 \\
\hline Accounting & 1.76 & 1.73 & 1.96 & 1.89 & 2.00 & 1.74 \\
\hline CIS & 1.60 & 1.85 & 1.63 & 1.65 & 1.69 & 1.74 \\
\hline Economics & 1.79 & 1.93 & 1.77 & 1.69 & 1.82 & 1.92 \\
\hline Finance & 2.30 & 2.21 & 2.17 & 1.82 & 2.20 & 1.95 \\
\hline IB & 2.16 & 2.03 & 1.92 & 2.10 & 1.99 & 2.32 \\
\hline Management & 1.86 & 2.02 & 2.08 & 1.78 & 1.90 & 1.84 \\
\hline Marketing & 1.94 & 2.01 & 1.59 & 1.73 & 1.85 & 1.68 \\
\hline School of Business & & 2.21 & 2.37 & 2.48 & 2.42 & 2.10 \\
\hline
\end{tabular}

Initially, it appeared that there were significant differences amongst the departments on both the Teaching Ability and Recommendation scores. We applied an ANOVA test, the results of which are presented in Tables 4 and 5. These results clearly indicate significant differences across the departments for the six semesters worth of data. This is an important finding since it indicates that the department measure may be the more appropriate standard to be used in promotion and tenure evaluations rather than using a universal measure, such as the overall school mean.

Obviously use of a global standard would be preferable and easier given the uniformity it would provide. However, the statistical differences between departments for Teaching Ability and Recommendation bring into question the validity and more importantly, the fairness of using a single global measure. Is the variation between departments due to the quality of teaching in each department or is it due to a wide variety of other factors unrelated to teaching effectiveness such as the subject material covered? These are the factors will be discussed in the conclusions and future research section of this paper. Failure to consider variations across departments can inflate a particular faculty evaluation or unjustly penalize the result. 
Table 4: ANOVA Results for Teaching Ability Measure for six semesters

\begin{tabular}{|l|c|c|c|c|c|}
\hline & Sum of Squares & df & Mean Squares & F & Significance \\
\hline Between Groups & 1201.19 & 7 & 117.60 & 150.83 & $>.001$ \\
\hline Within Groups & 32030.25 & 28153 & 1.14 & & \\
\hline Total & 33231.44 & 28160 & & & \\
\hline
\end{tabular}

Table 5: ANOVA Results for Recommendation of Teacher Measure for six semesters

\begin{tabular}{|l|c|c|c|c|c|}
\hline & Sum of Squares & df & Mean Squares & F & Significance \\
\hline Between Groups & 914.71 & 7 & 130.67 & 103.02 & $>.001$ \\
\hline Within Groups & 34565.59 & 27250 & 1.27 & & \\
\hline Total & 35480.30 & 25257 & & & \\
\hline
\end{tabular}

We have demonstrated that across the six semesters there are statistically significant differences amongst the departments on both the Teaching Ability and Recommendation scores. These results might reflect a difference that manifests itself in the aggregate. To test this assumption we ran ANOVA for both measures in each of the six semesters. The results are presented in Tables 6 to 17. All twelve ANOVA clearly indicated highly statistically significant $(>\mathbf{. 0 0 1})$ results that show there were differences across departments and that this is neither a transitory phenomenon nor a product of aggregating data.

It should be noted that starting with Spring of 2003, we added the results from three additional departments. One of these departments - School of Business courses was, in effect, created starting in that semester. The other two smaller departments were categorized as separate entities beginning with the Spring 2003 semester.

Table 6: ANOVA Results for Teaching Ability Measure by all Departments - Fall 2002

\begin{tabular}{|l|c|c|c|c|c|}
\hline & Sum of Squares & Df & Mean Squares & F & Significance \\
\hline Between Groups & 161.39 & 7 & 23.06 & 20.68 & $>.001$ \\
\hline Within Groups & 4798.76 & 4304 & 1.12 & & \\
\hline Total & 4960.15 & 4311 & & & \\
\hline
\end{tabular}

Table 7: ANOVA Results for Recommendation of Teacher Measure by all Departments - Fall 2002

\begin{tabular}{|l|c|c|c|c|c|}
\hline & Sum of Squares & df & Mean Squares & F & Significance \\
\hline Between Groups & 160.37 & 7 & 22.91 & 18.23 & $>.001$ \\
\hline Within Groups & 5268.15 & 4191 & 1.26 & & \\
\hline Total & 5428.52 & 4198 & & & \\
\hline
\end{tabular}

Table 8: ANOVA Results for Teaching Ability Measure by all Departments - Spring 2003

\begin{tabular}{|l|c|c|c|c|c|}
\hline & Sum of Squares & Df & Mean Squares & F & Significance \\
\hline Between Groups & 123.49 & 10 & 12.35 & 10.51 & $>.001$ \\
\hline Within Groups & 5398.56 & 4594 & 1.18 & & \\
\hline Total & 5522.05 & 4604 & & & \\
\hline
\end{tabular}


Table 9: ANOVA Results for Recommendation of Teacher Measure by all Departments - Spring 2003

\begin{tabular}{|l|c|c|c|c|c|}
\hline & Sum of Squares & df & Mean Squares & F & Significance \\
\hline Between Groups & 162.45 & 10 & 16.25 & 12.42 & $>.001$ \\
\hline Within Groups & 5869.43 & 4488 & 1.31 & & \\
\hline Total & 6031.89 & 4498 & & & \\
\hline
\end{tabular}

Table 10: ANOVA Results for Teaching Ability Measure by all Departments - Fall 2003

\begin{tabular}{|l|c|c|c|c|c|}
\hline & Sum of Squares & Df & Mean Squares & F & Significance \\
\hline Between Groups & 367.84 & 10 & 36.78 & 33.40 & $>.001$ \\
\hline Within Groups & 5878.52 & 5337 & 1.10 & & \\
\hline Total & 6246.37 & 5347 & & & \\
\hline
\end{tabular}

Table 11: ANOVA Results for Recommendation of Teacher Measure by all Departments - Fall 2003

\begin{tabular}{|l|c|c|c|c|c|}
\hline & Sum of Squares & df & Mean Squares & F & Significance \\
\hline Between Groups & 421.47 & 10 & 42.15 & 33.29 & $>.001$ \\
\hline Within Groups & 6600.04 & 5213 & 1.27 & & \\
\hline Total & 7021.51 & 5223 & & & \\
\hline
\end{tabular}

Table 12: ANOVA Results for Teaching Ability Measure by all Departments - Spring 2004

\begin{tabular}{|l|c|c|c|c|c|}
\hline & Sum of Squares & Df & Mean Squares & F & Significance \\
\hline Between Groups & 422.38 & 10 & 42.24 & 41.82 & $>.001$ \\
\hline Within Groups & 5435.21 & 5383 & 1.01 & & \\
\hline Total & 5857.58 & 5393 & & & \\
\hline
\end{tabular}

Table 13: ANOVA Results for Recommendation of Teacher Measure by all Departments - Spring 2004

\begin{tabular}{|l|c|c|c|c|c|}
\hline & Sum of Squares & df & Mean Squares & F & Significance \\
\hline Between Groups & 470.53 & 10 & 47.05 & 41.27 & $>.001$ \\
\hline Within Groups & 6029.54 & 5275 & 1.14 & & \\
\hline Total & 6500.07 & 5285 & & & \\
\hline
\end{tabular}

Table 14: ANOVA Results for Teaching Ability Measure by all Departments - Fall 2004

\begin{tabular}{|l|c|c|c|c|c|}
\hline & Sum of Squares & Df & Mean Squares & F & Significance \\
\hline Between Groups & 824.29 & 10 & 82.43 & 68.69 & $>.001$ \\
\hline Within Groups & 6241.73 & 5201 & 1.20 & & \\
\hline Total & 7066.02 & 5211 & & & \\
\hline
\end{tabular}

Table 15: ANOVA Results for Recommendation of Teacher Measure by all Departments - Fall 2004

\begin{tabular}{|l|c|c|c|c|c|}
\hline & Sum of Squares & df & Mean Squares & F & Significance \\
\hline Between Groups & 175.60 & 10 & 17.56 & 13.68 & $>.001$ \\
\hline Within Groups & 6207.09 & 4837 & 1.28 & & \\
\hline Total & 6382.69 & 4847 & & & \\
\hline
\end{tabular}


Table 16: ANOVA Results for Teaching Ability Measure by all Departments - Spring 2005

\begin{tabular}{|l|c|c|c|c|c|}
\hline & Sum of Squares & Df & Mean Squares & F & Significance \\
\hline Between Groups & 176.11 & 10 & 16.61 & 16.61 & $>.001$ \\
\hline Within Groups & 4994.73 & 4712 & 1.06 & & \\
\hline Total & 5170.84 & 4722 & & & \\
\hline
\end{tabular}

Table 17: ANOVA Results for Recommendation of Teacher Measure by all Departments - Spring 2005

\begin{tabular}{|l|c|c|c|c|c|}
\hline & Sum of Squares & df & Mean Squares & F & Significance \\
\hline Between Groups & 192.35 & 10 & 19.24 & 15.48 & $>.001$ \\
\hline Within Groups & 5716.41 & 4600 & 1.24 & & \\
\hline Total & 5908.76 & 4610 & & & \\
\hline
\end{tabular}

\section{CONCLUSIONS}

SEIs are one of the most widely used measures of evaluating teaching effectiveness. As a result, SEIs play an important role in tenure, merit raises, and promotion decisions. It is critical that SEIs be interpreted with care and attention given to variables unrelated to instructional factors that may affect the outcome.

Particular attention should be given to the standard by which to measure performance. Our research findings indicate that there are significant differences across departments. As a result, for promotion and tenure decisions, consideration should be given to the use of department measures in evaluations rather than a universal measure, such as the overall school mean. Prior studies primarily focused on the SEI instrument without analysis of the appropriate measurement standard.

This research provides empirical data to support the use of a more appropriate standard to adequately assess teaching effectiveness. The measurement standard (overall school versus department) must be considered in the evaluation process. In this way, the SEI evaluation process can more accurately appraise teaching ability. Extensive support exists for continued use of student evaluation instruments; however, the standard by which they are measured may change as a result of considerations presented in this research.

\section{FUTURE RESEARCH}

This research analyzed the appropriate measurement standard for comparison with an individual faculty member's SEI results. However, the data collected allows us to investigate a variety of factors for future research. Influence of course type (requirement for business core, requirement for the major, or an elective requirement) on the evaluation of the instructor both on Teaching Ability and Willingness to Recommend can be analyzed. The existing literature indicates that the requirement status of the course and where it falls in the curriculum impacts a student's perception and resulting evaluation of the instructor (Marsh, 1987; Feldman, 1978). . Since course requirement status appears to influence ratings then consideration must be given to this factor when evaluating a faculty member.

The data will also allow us to review the impact of students' status (freshman, sophomore, junior, senior and graduate) on evaluations. The distinction between undergraduate and graduate courses may prove to be a mitigating factor. With respect to the student's anticipated grade and their evaluation of the instructor's teaching, our future research could confirm prior research (Nelson and Lynch 1984; Mehdizadeh 1990; Stratton et al. 1994; Isley and Singh 2005; McPherson 2006) where lower evaluations resulted from lower anticipated grades and higher anticipated grades resulted in higher teaching evaluations.

The impact of class size on ratings will be investigated as well. The influence of class size on SEIs in the existing literature appears to be mixed. Hill (1998) noted that class size did not appear to have any effect on the 
student's overall perception of the professor's effectiveness. Drago and Peltier's (2004) results also found that instructor-student interaction was not significantly impacted by the number of students for online courses. Conversely, Liaw and Goh (2003) provide evidence that partiality exists for economics instructors with smaller class sizes versus those with larger enrollments. Shu-Hui Liaw et al. (2003) also demonstrated good overall teaching ratings for small classes and poor evaluations for larger classes. While Feldman (1984) also noted a relationship between class size and teaching evaluation ratings, his findings indicated a $U$ shape relationship where higher ratings were recorded for relatively small and relatively large classes. Additionally, McPherson (2006) and Badri et al. (2006) found class size to be an important indicator of student evaluation of teaching. It will be interesting to investigate how and if class size influenced the results at our School of Business.

In addition, the data will allow us to review instructor course workload (number of courses and preparations per semester) relative to ratings. Did fewer courses and preparations mean higher evaluations? This issue does not appear to be addressed in the existing literature. As a result, extension of this study to include instructor workload may significantly add to how the evaluation instrument is interpreted

Other researchers may duplicate the methodology employed by this study to investigate whether the results at their institutions are similar. If statistically significant differences amongst departments are noted on future research, this potentially could lead to a change in the standard by which an individual faculty's members SEIs are compared. 


\section{APPENDIX 1}

\begin{tabular}{|c|c|c|c|c|c|}
\hline You are a: & Freshman & Sophomore & Junior & Senior & $\begin{array}{c}\text { Graduate } \\
\text { Student } \\
\end{array}$ \\
\hline Is this course: & $\begin{array}{l}\text { Required for } \\
\text { Core }\end{array}$ & $\begin{array}{l}\text { Required for } \\
\text { Major }\end{array}$ & Elective & & \\
\hline Rate the instructor's teaching ability in this class & Poor & Fair & Good & Very Good & Excellent \\
\hline $\begin{array}{l}\text { How are you doing in keeping up with } \\
\text { assignments and readings - Percent complete: }\end{array}$ & $0-20 \%$ & $21-40 \%$ & $41-60 \%$ & $61-80 \%$ & $81-100 \%$ \\
\hline Expected Grade: & $\mathrm{A}$ & $\mathrm{B}$ & $\mathrm{C}$ & $\mathrm{D}$ & $\mathrm{F}$ \\
\hline $\begin{array}{l}\text { I have become more competent in this area due } \\
\text { to this course. }\end{array}$ & $\begin{array}{c}\text { Strongly } \\
\text { Agree } \\
1 \\
\end{array}$ & $\begin{array}{l}\text { Agree } \\
2\end{array}$ & $\begin{array}{l}\text { Neither } \\
3\end{array}$ & $\begin{array}{l}\text { Disagree } \\
4\end{array}$ & $\begin{array}{c}\text { Strongly } \\
\text { Disagree } \\
5\end{array}$ \\
\hline $\begin{array}{l}\text { I have increased my overall knowledge of the } \\
\text { subject matter. }\end{array}$ & $\begin{array}{c}\text { Strongly } \\
\text { Agree } \\
1 \\
\end{array}$ & $\begin{array}{l}\text { Agree } \\
2\end{array}$ & $\begin{array}{l}\text { Neither } \\
3\end{array}$ & $\begin{array}{c}\text { Disagree } \\
\quad 4\end{array}$ & $\begin{array}{c}\text { Strongly } \\
\text { Disagree } \\
5\end{array}$ \\
\hline I feel challenged intellectually by this course. & $\begin{array}{l}\text { Strongly } \\
\text { Agree } \\
1\end{array}$ & $\begin{array}{l}\text { Agree } \\
2\end{array}$ & $\begin{array}{c}\text { Neither } \\
3\end{array}$ & $\begin{array}{l}\text { Disagree } \\
\quad 4\end{array}$ & $\begin{array}{c}\text { Strongly } \\
\text { Disagree } \\
5\end{array}$ \\
\hline The instructor presents the material too rapidly. & $\begin{array}{c}\text { Strongly } \\
\text { Agree } \\
1 \\
\end{array}$ & $\begin{array}{l}\text { Agree } \\
2\end{array}$ & $\begin{array}{c}\text { Neither } \\
3\end{array}$ & $\begin{array}{l}\text { Disagree } \\
\quad 4\end{array}$ & $\begin{array}{c}\text { Strongly } \\
\text { Disagree } \\
5 \\
\end{array}$ \\
\hline $\begin{array}{l}\text { The instructor gives assignments are too } \\
\text { difficult. }\end{array}$ & $\begin{array}{c}\text { Strongly } \\
\text { Agree } \\
1 \\
\end{array}$ & $\begin{array}{l}\text { Agree } \\
2\end{array}$ & $\begin{array}{l}\text { Neither } \\
3\end{array}$ & $\begin{array}{l}\text { Disagree } \\
\quad 4\end{array}$ & $\begin{array}{c}\text { Strongly } \\
\text { Disagree } \\
5 \\
\end{array}$ \\
\hline The instructor is available to provide extra help. & $\begin{array}{c}\text { Strongly } \\
\text { Agree } \\
1 \\
\end{array}$ & $\begin{array}{l}\text { Agree } \\
2\end{array}$ & $\begin{array}{c}\text { Neither } \\
3\end{array}$ & $\begin{array}{l}\text { Disagree } \\
\quad 4\end{array}$ & $\begin{array}{c}\text { Strongly } \\
\text { Disagree } \\
5\end{array}$ \\
\hline $\begin{array}{l}\text { The instructor provides clear answers to the } \\
\text { student questions. }\end{array}$ & $\begin{array}{l}\text { Strongly } \\
\text { Agree } \\
1\end{array}$ & $\begin{array}{l}\text { Agree } \\
2\end{array}$ & $\begin{array}{c}\text { Neither } \\
3\end{array}$ & $\begin{array}{l}\text { Disagree } \\
4\end{array}$ & $\begin{array}{c}\text { Strongly } \\
\text { Disagree } \\
5 \\
\end{array}$ \\
\hline The instructor encourages class discussion. & $\begin{array}{c}\text { Strongly } \\
\text { Agree } \\
1 \\
\end{array}$ & $\begin{array}{l}\text { Agree } \\
2\end{array}$ & $\begin{array}{c}\text { Neither } \\
3\end{array}$ & $\begin{array}{l}\text { Disagree } \\
\quad 4\end{array}$ & $\begin{array}{c}\text { Strongly } \\
\text { Disagree } \\
5\end{array}$ \\
\hline $\begin{array}{l}\text { The instructor brings current ideas to the } \\
\text { classroom. }\end{array}$ & $\begin{array}{c}\text { Strongly } \\
\text { Agree } \\
1 \\
\end{array}$ & $\begin{array}{l}\text { Agree } \\
2\end{array}$ & $\begin{array}{l}\text { Neither } \\
3\end{array}$ & $\begin{array}{l}\text { Disagree } \\
\quad 4\end{array}$ & $\begin{array}{c}\text { Strongly } \\
\text { Disagree } \\
5 \\
\end{array}$ \\
\hline The instructor has the course well organized. & $\begin{array}{c}\text { Strongly } \\
\text { Agree } \\
1 \\
\end{array}$ & $\begin{array}{l}\text { Agree } \\
2\end{array}$ & $\begin{array}{c}\text { Neither } \\
3\end{array}$ & $\begin{array}{l}\text { Disagree } \\
\quad 4\end{array}$ & $\begin{array}{c}\text { Strongly } \\
\text { Disagree } \\
5 \\
\end{array}$ \\
\hline $\begin{array}{l}\text { The instructor summarizes main points and } \\
\text { provides emphasis on material. }\end{array}$ & $\begin{array}{c}\text { Strongly } \\
\text { Agree } \\
1 \\
\end{array}$ & $\begin{array}{l}\text { Agree } \\
2\end{array}$ & $\begin{array}{c}\text { Neither } \\
3\end{array}$ & $\begin{array}{l}\text { Disagree } \\
\quad 4\end{array}$ & $\begin{array}{c}\text { Strongly } \\
\text { Disagree } \\
5\end{array}$ \\
\hline $\begin{array}{l}\text { The instructor relates course concepts in } \\
\text { systematic fashion. }\end{array}$ & $\begin{array}{c}\text { Strongly } \\
\text { Agree } \\
1 \\
\end{array}$ & $\begin{array}{l}\text { Agree } \\
2\end{array}$ & $\begin{array}{c}\text { Neither } \\
3\end{array}$ & $\begin{array}{l}\text { Disagree } \\
\quad 4\end{array}$ & $\begin{array}{c}\text { Strongly } \\
\text { Disagree } \\
5 \\
\end{array}$ \\
\hline The instructor seems to enjoy teaching. & $\begin{array}{c}\text { Strongly } \\
\text { Agree } \\
1 \\
\end{array}$ & $\begin{array}{l}\text { Agree } \\
2\end{array}$ & $\begin{array}{c}\text { Neither } \\
3\end{array}$ & $\begin{array}{l}\text { Disagree } \\
\quad 4\end{array}$ & $\begin{array}{c}\text { Strongly } \\
\text { Disagree } \\
5 \\
\end{array}$ \\
\hline $\begin{array}{l}\text { The instructor is friendly and considerate to } \\
\text { students. }\end{array}$ & $\begin{array}{c}\text { Strongly } \\
\text { Agree } \\
1 \\
\end{array}$ & $\begin{array}{l}\text { Agree } \\
2\end{array}$ & $\begin{array}{c}\text { Neither } \\
3\end{array}$ & $\begin{array}{c}\text { Disagree } \\
\quad 4\end{array}$ & $\begin{array}{c}\text { Strongly } \\
\text { Disagree } \\
5 \\
\end{array}$ \\
\hline $\begin{array}{l}\text { The instructor is enthusiastic about the course } \\
\text { material. }\end{array}$ & $\begin{array}{c}\text { Strongly } \\
\text { Agree } \\
1 \\
\end{array}$ & $\begin{array}{l}\text { Agree } \\
2\end{array}$ & $\begin{array}{l}\text { Neither } \\
3\end{array}$ & $\begin{array}{c}\text { Disagree } \\
4\end{array}$ & $\begin{array}{c}\text { Strongly } \\
\text { Disagree } \\
5\end{array}$ \\
\hline $\begin{array}{l}\text { I would recommend taking another course with } \\
\text { this instructor to a friend. }\end{array}$ & $\begin{array}{l}\text { Strongly } \\
\text { Agree } \\
1\end{array}$ & $\begin{array}{l}\text { Agree } \\
2\end{array}$ & $\begin{array}{l}\text { Neither } \\
3\end{array}$ & $\begin{array}{c}\text { Disagree } \\
\quad 4\end{array}$ & $\begin{array}{c}\text { Strongly } \\
\text { Disagree } \\
5\end{array}$ \\
\hline
\end{tabular}




\section{AUTHOR INFORMATION}

Kathleen Simione is an Assistant Professor of Accounting at Quinnipiac University. She holds an MBA from Quinnipiac University and a BS in Accounting from Bentley University. Ms. Simione also holds a CPA certificate in Connecticut. Prior to teaching, she worked in both public and private accounting. Her research includes accounting and business education.

Dr. David T. Cadden received his undergraduate degree in Civil Engineering from Brooklyn Polytechnic Institute and his MBA and Doctorate from the City University of New York. His research interests are currently focused on application of quality improvement methods in education and the application of neural network systems in finance.

Angela Mattie is an assistant professor of management at Quinnipiac University. Prior to joining Quinnipiac, Angela held senior management positions in acute and managed care settings. In 2000-2001, she was selected as a Robert Wood Johnson Health Policy Fellow and served as a staff member of the U.S. Senate Health, Education, Labor and Pensions Committee. Ms. Mattie received her Master's Degree in Public Health, (M.P.H.) with distinction from Yale University School of Medicine, Department of Epidemiology and Public Health, a Juris Doctorate (J.D.) at the University of Connecticut School of Law, and an undergraduate degree, summa cum laude from Quinnipiac.

\section{REFERENCES}

1. Aigner, Dennis J., and Frederick D. Thum. 1986. On student evaluation of teaching ability. Journal of Economic Education 17 (4): 243-265.

2. Aleamoni, L.M. 1999. Student rating myths versus research facts from 1924 to 1998. Journal of Personnel Evaluation in Education 13 (2): 153-166.

3. Al-Issa, A. \& Sulieman, H. 2007. Student evaluations of teaching: perceptions and biasing factors. Quality Assurance in Education 15 (3): 302-317.

4. Badri, Masood A., Mohammed Abdulla, Mohammed A. Kamali and Hamzeh Dodeen. 2006. Identifying potential biasing variables in student evaluation of teaching in a newly accredited business program in the UAE. The International Journal of Educational Management 20 (1): 43-60.

5. Blackwell, Lloyd J., 1983. A statistical interpretation of student evaluation feedback: A comment. Journal of Economic Education 14 (3): 28-31.

6. Boex, L.F. Jameson. 2000. Attributes of effective economics instructors: An analysis of student evaluations. Journal of Economic Education 31 (3): 211-227.

7. Brightman, Harvey J., Merwy L. Elliot, and Yezdi Bhada. 1993. Increasing the effectiveness of student evaluation of instructor data through a factor score comparative report. Decision Sciences 24 (1): 192-199.

8. Campbell, Heather E., Gredes, Karen; Steiner, Sue. 2005. What's looks got to do with it? Instructor appearance and student evaluations of teaching. Journal of Policy Analysis and Management 24(3): 611620. Retrieved February 10, 2008, from ABI/INFORM Global database. (Document ID: 857258371).

9. Clayson, Dennis E., and Mary Jane Sheffet. 2006. Personality and the student evaluation of teaching. Journal of Marketing Education 28 (2): 149-160.

10. Comm, C.L., and Mathaisel, D. 1998. Evaluating teaching effectiveness in America's business schools: implications for service marketers. Journal of Professional Services Marketing 16 (2): 163-170.

11. Dee, Kay C., 2007. Student Perceptions of High Course Workloads are Not Associated with Poor Student Evaluations of Instructor Performance. Journal of Engineering Education 96(1), 69-78.

12. Drago, William and Jimmy Peltier. 2004. The effects of class size on effectiveness of online courses. Management Research News 27 (10): 27-36.

13. Feldman, K.A. 1984. Class size and college students' evaluations of teachers and courses: a closer look. Research in Higher Education 21 (1): 45-116.

14. Feldman, K.A. 1978. Course characteristics and variability among college students in rating their teachers and courses: A review and analysis. Research in Higher Education 9: 199-242.

15. Feldman, K.A. 1978. Course characteristics and college students' ratings of their teachers and courses. Research in Higher Education 9: 199-242. 
16. Glynn, Joseph G., Paul L. Sauer, and Gregory R. Wood. 2006. Dimensionality of a student evaluation of teaching scale: A ten year review. Academy of Educational Leadership Journal 10 (2): 45-53.

17. Gramlich, Edward M., and Glen A. Greenlee. 1993. Measuring teaching performance. Journal of Economic Education 24 (1): 3-13.

18. Green, Brian P., Thomas G. Calderon, and Barbara P. Reider. 1998. A content analysis of teaching evaluation instruments used in accounting departments. Issues in Accounting Education 13 (1): 15-30.

19. Hammermesh, D.S., \& Parker, A.M. 2003, July. Beauty in the classroom: Professors' pulchritude and putative pedagogical productivity. Unpublished paper, University of Texas at Austin. Forthcoming, Economics of Educational Review.

20. Hill, Mary C. 1998. Class size and student performance in introductory accounting courses: Further evidence. Issues in Accounting Education 13 (1): 47-64.

21. Isely, Paul and Harin Singh. 2005. Do higher grades lead to favorable student evaluations? Journal of Economic Education 36 (1): 29-42.

22. Hobson, S. M., \& Talbot, D. M. 2001. "Understanding student evaluations.” College Teaching 49(1), 2631.

23. Holmes, Linda E., and Lois J. Smith. 2003. Student evaluations of faculty grading methods. Journal of Education for Business 78 (6): 318-323.

24. Isely, Paul., \& Singh, Harinder. (2005). Do Higher Grades Lead to Favorable Student Evaluations? Journal of Economic Education 36 (1): 29-42.

25. Kanagaretnam, Kiridaran, Robert Mathieu and Alex Thevaranjan. 2003. An economic analysis of the use of student evaluations: Implications for universities. Managerial and Decision Economics 24 (1): 1-13.

26. Kau, J. and Rubin, P. 1976. Measurement techniques, grades and rating instructors. Journal of Economic Education 8 (1): 59-62.

27. Kulik, A. 2001, Spring. Student ratings: Validity, utility, and controversy. New Directions for Institutional Research 109: 9-25.

28. Lawson, Luther D. 2005. The correlation between teaching attributes and the instructor's rating. Journal of Economics and Economic Education Research 6 (3): 93-103.

29. Liaw, Shu-Hui and Kim-Leng Goh. 2003. Evidence and control of biases in student evaluations of teaching. The International Journal of Educational Management 17 (1): 37-43.

30. Marsh, H.W. 1987. Students' evaluations of university teaching: Research findings, methodological issues, and directions for future research. International Journal of Educational Research 11(Whole Issue No. 3).

31. March, H.W. 1984. Students' evaluations of university teaching: Dimensionality, reliability, and validity, potential biases, and utility. Journal of Educational Psychology 76: 255-379.

32. McPherson, Michael A. 2006. Determinants of how students evaluate teachers. Journal of Economic Education 37(1): 3-21.

33. Mehdizadeh, Mostafa, 1990. Loglinear models and student course evaluations. Journal of Economic Education 21 (1): 7-21.

34. Morgan, Donald A., John Sneed and Laurie Swinney. 2003. Are student evaluations a valid measure of teaching effectiveness: Perceptions of accounting faculty members and administrators. Management Research News 26 (7): 17-32.

35. Mulford, C., and Schneider, A. 1988. An empirical study of structural and controllable factors affecting faculty evaluations. Advances in Accounting 205-215.

36. Nelson, Jon P., and Kathleen A. Lynch. 1984. Grade inflation, real income, simultaneity, and teaching evaluations. Journal of Economic Education 14 (1): 21-37.

37. Paswan, Audhesh, K., Young,Joyce A . 2002. Student evaluation of instructor: A nomological investigation using structural equation modeling. Journal of Marketing Education 24(3): 193-202.

38. Richardson, J. T. E. (2005). Instruments for obtaining student feedback: A review of the literature. Assessment \& Evaluation in Higher Education 30(4): 387-415.

39. Seiler, Vicky L., and Michael J. Seiler. 2002. Professors who make the grade. Review of Business 23 (2): $39-44$.

40. Seldin, P. 1993. The use and abuse of student ratings of professors. Chronicle of Higher Education 39 (46): A40. 
41. Shmanske, Stephen, 1988. On the measurement of teacher effectiveness. Journal of Economic Education 19 (4): 307-314.

42. Shu-Hui Liaw, Kim-Leng Goh. 2003. Evidence and control of biases in student evaluations of teaching. The International Journal of Educational Management 17(1): 37-43. Retrieved February 10, 2008, from ABI/INFORM Global database. (Document ID: 291990071).

43. Simpson, Penny M., and Judy A. Siguaw. 2000. Student evaluations of teaching: An exploratory study of faculty response. Journal of Marketing Education 22 (3): 199-213.

44. Smith, Bettye P. 2007. Student ratings of teaching effectiveness: An Analysis of end-of-course faculty evaluations. College Student Journal A 41(4): 788-800. Retrieved February 10, 2008, from ProQuest Psychology Journals database. (Document ID: 1408086101).

45. Smith, G. \& Anderson, K.J. 2005. Students' ratings of professors: The teaching style contingency for Latino/a professors. Journal of Latinos and Education 4(2): 115-136 (in Smith).

46. Soper, John C., 1973. Soft research: Student evaluations reconsidered. Journal of Economic Education 5 (1): $22-26$.

47. Stapelton, Richard J., and Gene Murison. 2001. Optimizing the fairness of student evaluations: A study of correlations between instructor excellence, study production, learning production, and expected grades. Journal of Management Education 25 (3): 269-291.

48. Stratton, Richard W., Myers, Steven C., and King, Randall H. 1994. Faculty behavior, grades, and student evaluations. Journal of Economic Education 25 (1): 5-15.

49. Thomas, Jennifer D. E., 2003. A rubric for the evaluation of interactive multimedia and the impact of instruction on students' evaluations. The Journal of Computer Information Systems 43 (4): 32- 40.

50. Watchtel, H.K. 1998. Student evaluation of college teaching effectiveness: A brief review. Assessment and Evaluation in Higher Education 23(2): 191-211.

51. Wilson, R. 1998. New research casts doubt on value of student evaluations of professors. The Chronicle of Higher Education 44 (19): 12-15.

52. Young, Phillip, Dane A. Delli and Leroy Johnson. 1999. Student evaluation of faculty: Effects of purpose on pattern. Journal of Personnel Evaluation in Education 13 (2): 179-190.

53. Yunker, Penelope J., and Yunker, James A. 2003. Are student evaluations of teaching valid? Evidence form an analytical business course. Journal of Education for Business 78 (6): 313-317. 